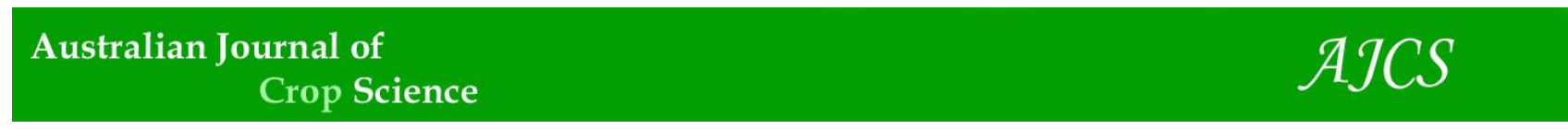

AJCS 10(11):1564-1571 (2016)

ISSN:1835-2707

doi: 10.21475/ajcs.2016.10.11.PNE183

\title{
Wet and dry corn yield under intercrop culivation with marandu grass and/or dwarf pigeon pea and nutritional value of the marandu grass in succession
}

\author{
Cássia Maria de Paula Garcia ${ }^{* 1}$, Ciniro Costa ${ }^{2}$, Paulo Roberto de Lima Meirelles ${ }^{2}$, Marcelo Andreotti ${ }^{1}$, \\ Cristiano Magalhães Pariz ${ }^{2}$, Leandro Alves Freitas ${ }^{1}$, Marcelo Carvalho Minhoto Teixeira Filho ${ }^{1}$
}

${ }^{1}$ Department of Plant Health, Rural Engineering, and Soils, Faculdade de Engenharia de Ilha Solteira, Universidade Estadual Paulista "Júlio de Mesquita Filho", Ilha Solteira, São Paulo State, Zip Code 15385-000, Brazil

${ }^{2}$ Department of Breeding and Animal Nutrition, Faculdade de Medicina Veterinária e Zootecnia, Universidade Estadual Paulista "Júlio de Mesquita Filho", Botucatu, São Paulo State, Zip Code 18.618-000, Brazil

\begin{abstract}
The aim of this study was to evaluate corn grain yield and dry matter yield and nutritional value of Urochloa brizantha cv. Marandu (marandu grass) in succession to an intercrop of corn with marandu grass and/or dwarf pigeon pea (Cajanus cajan cv. Anão) in a dryland area. The experiment was conducted during the crop years of 2013/14 and 2014/15, in a low-altitude Cerrado biome (savannah) experimental area. The experiment was set up as a randomized block design with six replications, in a $2 \times 2 \times 2$ factorial arrangement consisting of two intercrops [corn with marandu grass (CB) and corn with marandu grass and dwarf pigeon pea (CBP)]; two grain harvest times (wet and dry grain stages); and two consecutive years (2013/14 and 2014/15). Irrespective of the intercrop, the harvest of corn grain in the wet stage for silage minimized the losses caused by climatic factors. The intercrop of corn with marandu grass and dwarf pigeon pea reduced the yield of wet corn grains and the dry matter of the marandu grass in succession. Marandu grass in succession to the intercrop of corn with dwarf pigeon pea resulted in better nutritional value because of the lower fiber and higher total digestible nutrients contents.
\end{abstract}

Keywords: Cajanus cajan, Cerrado, Zea mays, pastures, Urochloa brizantha.

Abbreviations: CB_Corn with marandu grass; CBP_Corn with marandu grass and dwarf pigeon pea; WG_Wet-grain stage harvest; DG_ Dry-grain stage harvest; NT_ Intercropping grain crops with tropical forages under the no-till; GY_Corn grain yield; CP_Crude protein; NDF_Neutral detergent fiber; ADF_Acid detergent fiber; TDN_Total digestible nutrient; IVDMD_Indigestibility in vitro dry matter; DMY_ Dry matter yield; DM_ Dry matter; LIG_Lignin.

\section{Introduction}

The interests in intercropping grain crops with tropical forages under the no-till (NT) system has increased significantly by both technicians and producers in regions characterized by dry winters (Borghi and Crusciol, 2007). This fact is evidenced by the maintenance of an appropriate amount of plant residues on the soil, especially in the Brazilian Cerrado (savannah) conditions, which is more difficult by virtue of the weather that causes rapid decomposition and hinders production during the off-season (Muraishi et al., 2005). Borghi et al. (2007) evaluated the productive aspects of marandu grass (Urochloa brizantha $\mathrm{cv}$. Marandu) during the period that was intercropped with corn. After the harvest of grains in a NT system, they concluded that as the intercrop period progressed, the grass produced fewer leaves, stems, and sheaths. However, after the grains were harvested, the forage displayed great regrowth potential. Integrated crop-livestock production systems have been recognized as alternatives for sustainable intensification, as they are more efficient in the use of natural resources (Wright et al., 2012), promote nutrient cycling and soil improvement (Salton et al., 2014), decrease production costs (Ryschawy et al., 2012), keeping production levels high (Balbinot Jr et al., 2009), and also bring advantages to the ecosystem (Sanderson et al., 2013). These systems regained their importance after decades, during which monocropping systems predominated, characterized by little diversity and large use of inputs (Lemaire et al., 2014).

Intercropping is a versatile practice that can meet the different characteristics of producers, both for grain yield and production of silage with more protein, as is the case of intercrops with legumes, and for production of hay as a soil cover, providing higher profitability rates compared with monocrops (Santos et al., 2011). This intercropping system with legumes represents an alternative for the producer to implement nitrogen biological fixation in the production system (Brasil, 2010).

Legume plants stand out for their symbiotic relations with $\mathrm{N}_{2}$-fixing bacteria, and their low $\mathrm{C} / \mathrm{N}$ ratio, associated with the large presence of soluble compounds, promotes rapid decomposition and mineralization, with an expressive supply of $\mathrm{N}$ to the soil-plant system (Ferreira et al., 2011; Partelli et al., 2011). Further, legumes play an essential role as nutrient providers when a no-till system is established, since plants of this family have the advantage of promptly supplying nutrients to successive crops because of the rapid decomposition of their residues (Silveira et al., 2005).

It is interesting to note that the use of forage legume species intercropped with corn has been researched and generated positive results for grain yield (Heinrichs et al., 2005; Nunes et al., 2006). This particular emphasis on corn 
lies in the fact that it is the main cereal produced in Brazil, occupying an area of 13.8 million hectares, which represents $27.5 \%$ of the area sown with other annual crops in the 2010/11 harvest (Conab, 2012).

The legume species have been evaluated by many authors for their biomass production and nutrient supply to the soil when grown in an intercrop with corn or as a monocrop (Heinrichs et al., 2005; Carneiro et al., 2008). Besides, intercropping has an essential function in weed control, representing an important tool for organic crops (Oliveira et al., 2011). Most studies evaluating corn intercrops have focused the grain productivity, not prioritizing the dry matter, yield or the chemical composition of the forage in succession (Leonel et al., 2009). Therefore, the objective of the present study was to evaluate corn grain yield and dry matter yield and nutritive value of marandu grass in succession to an intercrop of corn with marandu grass and/or dwarf pigeon pea in a dryland area.

\section{Results}

\section{Productivity of wet grain and corn dry}

Table 1. shows the unfolding of the corn grain yield (GY) values as affected by the interactions between intercrops (CB and $\mathrm{CBP}$ ) and harvest times (WG and DG) and intercrops (CB and CBP) and crop years (2013/14 and 2014/15). By comparing the intercrops in relation to the corn harvest times, the corn GY was higher in both intercrops, when corn was harvested at WG stage, and between the two harvest times, the yield obtained at WG was higher in the CB intercrop. Regarding the intercrops within years, irrespective of the treatment, GY was higher in the first year. When we compared the years in relation to the intercrops, in the first year, the GY from $\mathrm{CB}$ was higher than that obtained with $\mathrm{CBP}$. In the second year there was no difference between the intercrops (Table 1).

\section{Chemical composition of marandu grass}

Table 2. presents the chemical composition of marandu grass after the harvest of corn intercropped with Urochloa brizantha cv. Marandu (CB) and with Urochloa brizantha cv. Marandu/dwarf pigeon pea (CBP), at both corn harvest times (WG and DG), in two consecutive years (2013/14 and 2014/15)

The forage in the CB intercrop had higher NDF, ADF, and hemicellulose contents, while the CBP intercrop resulted in a higher TDN content. The other chemical components did not present significant differences between intercrops. Regarding the harvest times, the forage showed higher cellulose contents when it was harvested with corn in the DG stage, whereas the other chemical components did not differ between the harvest times. Between the years, in the first year, the forage had higher hemicellulose, ash, and TDN levels, while in the second year higher NDF, ADF, cellulose, lignin, and IVDMD values were found (Table 2).

\section{Dry mass productivity of marandu grass}

The dry matter yield of the marandu grass after the harvest of wet and dry grains of the intercropped corn is given in Table 3. Overall, the corn harvest time (WG and DG) did not interfere with the total dry matter yield of the marandu grass, except for the first year, at the corn DG stage, in the CB intercrop, when the total DMY was higher. It was also higher in all the cutting periods (Table 3 ).

The ANOVA shows interaction between intercrop and harvest time referring to the forage dry matter yield $\left(\mathrm{kg} \mathrm{ha}^{-1}\right)$, in two years (Table 4). In the first year, the DMY of the forage originating from the CBP intercrop at the corn WG harvest time was higher as compared with the DG harvest time. Comparing the corn harvest time in relation to the intercrop, we observed that at DG harvest time, the forage DMY was higher in the CB intercrop. As for the second year, for both intercrops at the corn WG harvest time, the marandu grass had a higher DMY than at the corn DG harvest time, whereas at WG, the DMY of the forage from the $\mathrm{CB}$ intercrop was higher than that obtained with the CBP intercrop. The other interactions did not have significant differences (Table 4).

\section{Discussion}

\section{Productivity of wet grain and corn dry}

When the corn was harvested in the DG stage, overall, grain yield (GY) was lower (Table 1), due to the large amount of rain in the interval between the corn WG and DG harvest times, especially in the second years (Fig 2). This favored the appearance of fungi and rot of the ears; thus, contributing to a decline in productivity of dry corn grains. Studies investigating the intercropping of corn and marandu grass demonstrate the viability of this production system. The results of the present experiment corroborate with those obtained by Cobucci et al. (2001), who reported that the presence of the forage grass does not affect the productivity of corn grains. However, with the presence of dwarf pigeon pea, grain yield was lower due to the competition effect. Although some cases require application of nicosulfuron, at sub-doses, to reduce forage growth and ensure complete development of the corn, this practice was not necessary in our experiment, since the forages were sown deeper than the corn to avoid a possible competition.

It is worth mentioning that legume plants have a high $\mathrm{N}$ content that may benefit the corn crop. Senaratine et al. (1995) stated that the ability of this legume to make nitrogen available in the soil is highly variable among cultivars. According to Weber and Mielniczuk (2009) and Santos et al. (2010), in absence of nitrogen fertilization, the use of legumes preceding crops increases the corn yield. As reported by Silva et al. (2006), without nitrogen fertilization, the highest corn yields were obtained, when the preceding crop was a legume or fodder turnip. However in the present study, we must emphasis that the legume did not precede but was intercropped together with corn; thereby, competing for production factors during its cycles.

\section{Chemical composition of marandu grass}

In regard to the forage chemical components, the forage originating from the $\mathrm{CB}$ intercropping was more fibrous, probably due to the lower $\mathrm{N}$ accumulation in this area. However, this did not influence the CP, TDN, and IVDMD contents (Table 2). 
Table 1. Unfolding of the interactions between intercrop and corn harvest time; and intercrop and year, by analysis of variance referring to the yield of wet (WG) and dry (DG) corn grains $\left(\mathrm{kg} \mathrm{ha}^{-1}\right)$.

\begin{tabular}{lcc}
\hline & \multicolumn{2}{c}{ Harvest time } \\
\cline { 2 - 3 } Intercrop** & WG & DG \\
\hline CB & $7,027 \mathrm{aA}$ & $3,968 \mathrm{aB}$ \\
CBP & $5,581 \mathrm{bA}$ & $4,160 \mathrm{aB}$ \\
LSD & 1,034 & 1,034 \\
\hline & \multicolumn{2}{c}{ Year } \\
Intercrop* & $2013 / 14$ & $2014 / 15$ \\
\hline CB & $7,334 \mathrm{aA}$ & $3,662 \mathrm{aB}$ \\
CBP & $5,497 \mathrm{bA}$ & $4,245 \mathrm{aB}$ \\
LSD & 1,034 & 1,034 \\
\hline
\end{tabular}

*Means followed by common lowercase letters in the column and uppercase letters in the row do not differ statistically, according to Tukey's test at $5 \%$ probability level. $* * \mathrm{CB}$ (intercrop with corn and marandu grass); CBP (intercrop with corn/marandu grass/dwarf pigeon pea). ***DG (dry-grain stage harvest); WG (wet-grain stage harvest).

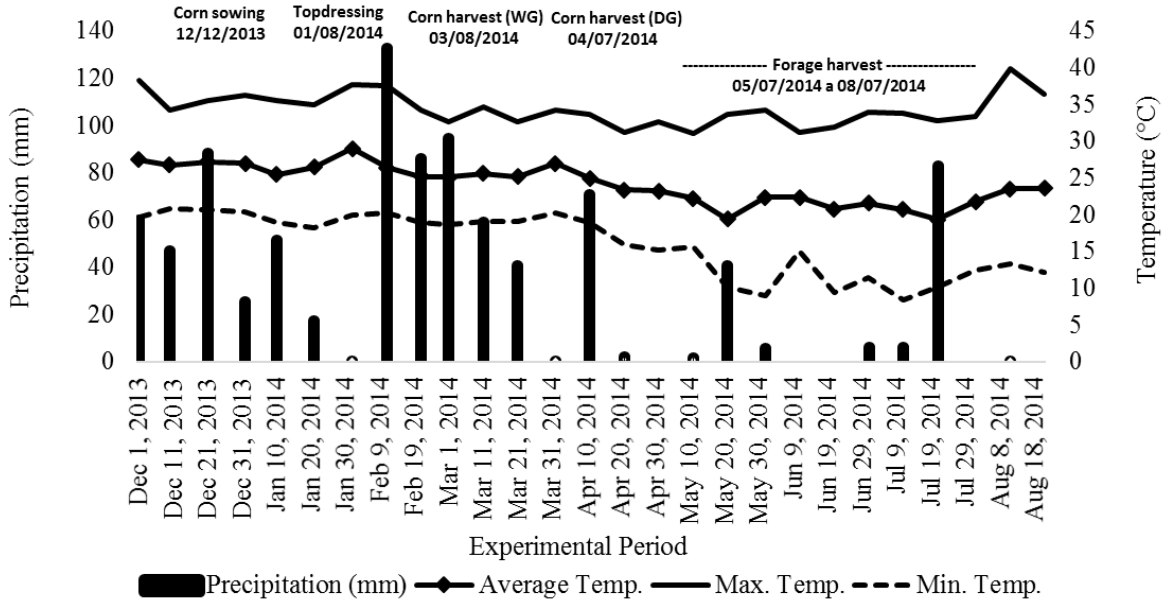

Fig 1. Precipitation $(\mathrm{mm})$, air relative humidity $(\%)$, and maximum, average and minimum temperatures $\left({ }^{\circ} \mathrm{C}\right)$ during the experiment in the 2013/14 harvest.

The forage was more fibrous also in the second year, compared to first year, displaying greater NDF, ADF, cellulose, and lignin contents, because in the second year. It was mainly due to the higher precipitation and temperatures (Fig 2). In the second year, the marandu grass showed greater development, accumulating more stems and consequently being more fibrous, although the TDN and IVDMD were not impaired by the increased fibrous contents of the forage, besides the high $\mathrm{CP}$ content.

According to Leite and Euclides (1994), the nutritional value of a forage species is influenced by soil fertility, climatic conditions, physiological age, and management procedures, to which it is subjected. Additionally, the dry matter accumulation of forage plants may be directly related to the availability of nutrients in the soil, which increases the dry matter yield of forage plants (Wilkins et al., 2000).

The nutritional value is also evaluated based on the digestibility and its $\mathrm{CP}$ and cell wall contents, which are characteristics closely related to DM intake. The forage quality depends on its components, which vary within the same species, according to the plant age, part of the plant, soil fertility, among other factors. The low nutritional value of the forages is associated with the reduced $\mathrm{CP}$, mineral contents, high fiber content and low DM digestibility (van Soest, 1994). The crude protein content and the acceptability by animals, coupled with satisfactory dry matter yield, are important factors in the choice of a cultivar for implementing the pasture (Maranhão et al., 2009).

The nutritional value of tropical grasses during the dry season is low. In most of the cases, CP contents do not reach the minimum value of $7.0 \%$, which is limiting to animal production, as it implies decreased digestibility and lower voluntary intake (Costa et al., 2005). Furthermore, higher mineral (ash) values are important, since in general, tropical grasses have deficiencies or limited concentrations of these elements (Pedreira and Berchielli, 2006).

In the present study, the $\mathrm{CP}$ contents of marandu grass were above the $7 \%$ reported by van Soest (1994) as the minimum for the maintenance of the population of microorganisms in the rumen of cattle, even in fall/winter harvests (Table 2). In this intercrop the forage was in its vegetative stage.

As stated by Silva and Queiroz (2002), cellulose represents the largest portion of $\mathrm{ADF}$, while hemicellulose integrates NDF and is calculated as the difference between NDF and $\mathrm{ADF}$, and is more digestible than cellulose. The NDF and ADF contents were higher than the 60 and 30\%, respectively, considered limiting by van Soest (1994), who pointed the DM intake by ruminants is reduced. The second year had high pluvial precipitation, with better distribution of rains associated with high temperatures (Fig 2), which contribute to greater forage growth in addition to high fiber contents (Table 2).

The total digestible nutrients content $(54 \%)$ was within the range reported by Benett et al. (2008) for marandu grass in the same cultivation area. The in vitro DM digestibility, in general, remained above $50 \%$. High temperatures promote rapid growth and development of leaves, which increase the cell wall components and consequently the participation of this component in the total plant dry matter. According to Wilson (1983), these effects are negatively correlated with IVDMD. Gerdes et al. (2000) found around 70\% IVDMD in the fall, similarly to the results obtained in the present study, 
Table 2. Nutritional value of marandu grass after an intercrop with corn and/or dwarf pigeon pea (CB and CBP), at two corn harvest times (WG and DG), in two consecutive years (2013/14 and 2014/15).

\begin{tabular}{|c|c|c|c|c|c|c|c|c|c|}
\hline Intercrop & $\begin{array}{l}\mathrm{CP} \\
(\%)\end{array}$ & $\begin{array}{l}\mathrm{NDF} \\
(\%)\end{array}$ & $\begin{array}{l}\mathrm{ADF} \\
(\%)\end{array}$ & $\begin{array}{c}\text { Cellulose } \\
(\%)\end{array}$ & $\begin{array}{l}\text { Hemicellulose } \\
(\%)\end{array}$ & $\begin{array}{l}\text { Lignin } \\
(\%)\end{array}$ & $\begin{array}{l}\text { Ash } \\
(\%)\end{array}$ & $\begin{array}{l}\text { TDN } \\
(\%)\end{array}$ & $\begin{array}{l}\text { IVDMD } \\
(\%)\end{array}$ \\
\hline $\mathrm{CB}$ & $12.30 \mathrm{a}$ & $65.71 \mathrm{a}$ & $40.03 a$ & $33.47 \mathrm{a}$ & $25.20 \mathrm{a}$ & $5.09 \mathrm{a}$ & $9.63 \mathrm{a}$ & $56.38 \mathrm{~b}$ & $72.91 \mathrm{a}$ \\
\hline CBP & $12.84 \mathrm{a}$ & $63.46 \mathrm{~b}$ & $39.77 \mathrm{~b}$ & $32.67 \mathrm{a}$ & $23.50 \mathrm{~b}$ & $5.02 \mathrm{a}$ & $9.76 \mathrm{a}$ & $57.32 \mathrm{a}$ & $73.49 \mathrm{a}$ \\
\hline \multicolumn{10}{|c|}{ Harvest time } \\
\hline WG & $12.71 \mathrm{a}$ & $64.23 \mathrm{a}$ & $39.70 \mathrm{a}$ & $32.60 \mathrm{~b}$ & $24.15 \mathrm{a}$ & $4.93 \mathrm{a}$ & $9.77 \mathrm{a}$ & $56.99 \mathrm{a}$ & $73.74 \mathrm{a}$ \\
\hline DG & $12.43 \mathrm{a}$ & $64.94 \mathrm{a}$ & $40.11 \mathrm{a}$ & $33.54 \mathrm{a}$ & $24.54 \mathrm{a}$ & $5.18 \mathrm{a}$ & $9.62 \mathrm{a}$ & $56.70 \mathrm{a}$ & $72.66 \mathrm{a}$ \\
\hline \multicolumn{10}{|l|}{ Year } \\
\hline 2013/14 & $12.80 \mathrm{a}$ & $63.83 b$ & $32.81 \mathrm{~b}$ & $28.05 \mathrm{~b}$ & $30.53 a$ & $3.12 b$ & $9.94 \mathrm{a}$ & $57.16 \mathrm{a}$ & $71.37 \mathrm{~b}$ \\
\hline $2014 / 15$ & $12.33 \mathrm{a}$ & $65.34 \mathrm{a}$ & $46.98 \mathrm{a}$ & $38.09 \mathrm{a}$ & $18.16 \mathrm{~b}$ & $6.99 \mathrm{a}$ & $9.45 \mathrm{~b}$ & $56.53 \mathrm{~b}$ & $75.03 \mathrm{a}$ \\
\hline LSD & 0.65 & 1.41 & 1.22 & 0.83 & 0.65 & 0.36 & 0.38 & 0.59 & 2.32 \\
\hline $\mathrm{CV}$ & 12.76 & 5.39 & 7.53 & 6.16 & 6.63 & 17.59 & 9.86 & 2.55 & 7.81 \\
\hline
\end{tabular}

grain stage harvest); WG (wet-grain stage harvest); CP (crude protein); NDF (neutral detergent fiber); $\mathrm{ADF}$ (acid detergent fiber); TDN (total digestible nutrient); IVDMD (indigestibility in vitro dry matter).

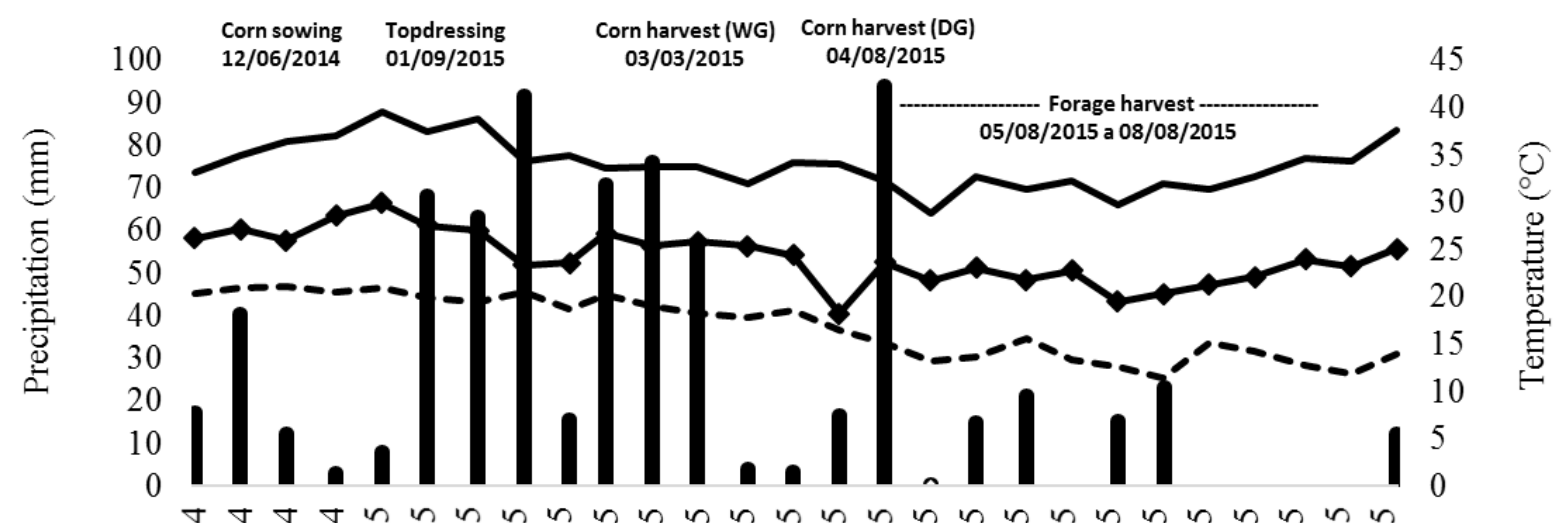

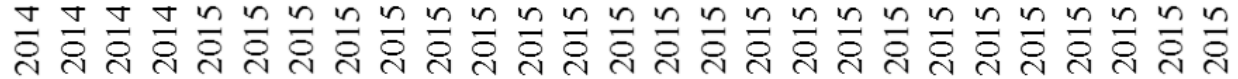

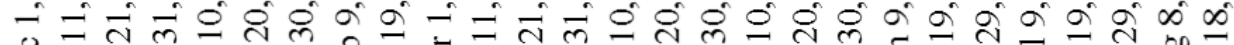

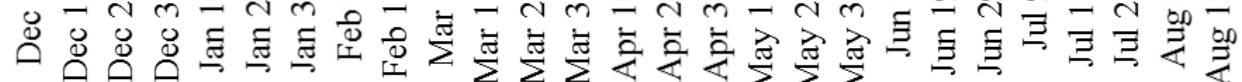
Experimental Period

Precipitation $(\mathrm{mm}) \longrightarrow$ Average Temp. $\longrightarrow$ Max. Temp. $\mathbf{-}$ - Min. Temp

Fig 2. Precipitation (mm), air relative humidity (\%), and maximum, average, and minimum temperatures $\left({ }^{\circ} \mathrm{C}\right)$ during the experiment in the $2014 / 15$ harvest. 
Table 3. Dry matter yield $\left(\mathrm{kg} \mathrm{ha}^{-1}\right)$ of marandu grass after the harvest of wet and dry corn grains in an intercrop. \begin{tabular}{lll}
\hline Corn harvest**** Intercrop** & Forage harvest
\end{tabular}

\begin{tabular}{lllllll} 
& \multicolumn{7}{c}{$\left(\mathrm{kg} \mathrm{DM} \mathrm{ha}^{-1}\right)$} \\
\cline { 3 - 7 } WG & & \multicolumn{7}{c}{$2013 / 14$} \\
03/08/2014 & CB & 3,400 & 3,400 & 5,736 & 3,376 & $15,912 \mathrm{a}$ \\
\hline LSD & CBP & 4,080 & 2,272 & 5,392 & 3,888 & $15,632 \mathrm{a}$ \\
\hline CV & & - & - & - & - & 4,519 \\
\hline DG & CB & - & - & - & - & 16.32 \\
$04 / 07 / 2014$ & CBP & - & 4,480 & 6,976 & 3,368 & $14,824 \mathrm{a}$ \\
\hline LSD & & - & 2,840 & 6,180 & 2,520 & $11,540 \mathrm{~b}$ \\
\hline CV & & - & - & - & - & 1,283 \\
\hline & - & - & - & - & 5.55 \\
WG & & & & $2014 / 15$ & \\
03/09/2015 & CB & $05 / 08$ & $06 / 08$ & $07 / 08$ & $08 / 08$ & Total \\
\hline LSD & CBP & 5,227 & 1,646 & 4,940 & 3,212 & $15,025 \mathrm{a}$ \\
\hline CV & & 3,330 & 1,502 & 3,627 & 3,967 & $12,426 \mathrm{a}$ \\
\hline DG & & - & - & - & - & 3,170 \\
$04 / 08 / 2015$ & CB & - & - & - & - & 10.27 \\
\hline LSD & & - & 3,608 & 2,762 & 1,595 & $7,965 \mathrm{a}$ \\
\hline CV & & - & 2,718 & 2,793 & 1,557 & $7,068 \mathrm{a}$ \\
\hline
\end{tabular}

*Means followed by common letters in the column within year and intercropping type do not differ statistically, according to Tukey's test at $5 \%$ probability level. **CB (intercrop with corn and marandu grass); CBP (intercrop with corn/marandu grass/dwarf pigeon pea). ***DG (dry-grain stage harvest); WG (wet-grain stage harvest).

Table 4. Unfolding of the interaction between intercrop and forage harvest time by analysis of variance referring to dry matter yield of the forage in two years $\left(\mathrm{kg} \mathrm{ha}^{-1}\right)$.

\begin{tabular}{lcc}
\hline Intercrop** & \multicolumn{3}{c}{ Harvest time $(2013 / 14)^{* * *}$} \\
\cline { 2 - 3 } & WG & DG \\
\hline CB & $15,912 \mathrm{aA}$ & $14,824 \mathrm{aA}$ \\
CBP & $15,632 \mathrm{aA}$ & $11,540 \mathrm{bB}$ \\
LSD & 2,283 & 2,283 \\
\hline Intercrop** & Harvest time $(2014 / 15)$ & \\
\hline CB & WG & DG \\
CBP & $15,025 \mathrm{aA}$ & $7,965 \mathrm{aB}$ \\
LSD & $12,426 \mathrm{bA}$ & $7,068 \mathrm{aB}$ \\
\hline
\end{tabular}

*Means followed by common lowercase letters in the column and uppercase letters in the row do not differ statistically, according to Tukey's test at $5 \%$ probability level.**CB (intercrop with corn and marandu grass); CBP (intercrop with corn/marandu grass/dwarf pigeon pea).***DG (dry-grain stage harvest); WG (wet-grain stage harvest).

Table 5. Soil chemical analysis in the 0-0.10 m layer. Selvíria, MS (2014/15)

\begin{tabular}{|c|c|c|c|c|c|c|c|c|c|c|c|c|c|}
\hline $\mathrm{P}_{\text {(resin) }}$ & $\mathrm{S}-\mathrm{SO}_{4}$ & OM & $\mathrm{pH}$ & $\mathrm{H}+\mathrm{Al}$ & $\mathrm{K}^{+}$ & $\mathrm{Ca}^{2+}$ & $\mathrm{Mg}^{2+}$ & $\mathrm{Al}$ & SB & $\mathrm{Cu}$ & $\mathrm{Fe}$ & $\mathrm{Mn}$ & $\mathrm{Zn}$ \\
\hline $\mathrm{mg} \mathrm{dm}{ }^{-3}$ & $\mathrm{mg} \mathrm{dm}{ }^{-3}$ & $\mathrm{mg} \mathrm{dm}^{-3}$ & $\begin{array}{c}\mathrm{CaCl}_{2} \\
0,01 \mathrm{~mol} \mathrm{~L}^{-1}\end{array}$ & ----. & & 1 & & --- & $(\%)$ & -- & 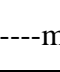 & $d$ & ---- \\
\hline 62 & 5 & 21 & 4.8 & 38 & 1.6 & 12 & 10 & 3 & 38 & 2.6 & 26 & 21 & 1.2 \\
\hline
\end{tabular}

Table 6. Soil chemical analysis in the 0.10-0.20 m layer. Selvíria, MS (2014/15).

\begin{tabular}{|c|c|c|c|c|c|c|c|c|c|c|c|c|c|}
\hline $\mathrm{P}_{\text {(resin) }}$ & $\mathrm{S}-\mathrm{SO}_{4}$ & $\mathrm{OM}$ & $\mathrm{pH}$ & $\mathrm{H}+\mathrm{Al}$ & $\mathrm{K}^{+}$ & $\mathrm{Ca}^{2+}$ & $\mathrm{Mg}^{2+}$ & $\mathrm{Al}$ & SB & $\mathrm{Cu}$ & $\mathrm{Fe}$ & $\mathrm{Mn}$ & $\mathrm{Zn}$ \\
\hline $\mathrm{mg} \mathrm{dm}^{-3}$ & $\mathrm{mg} \mathrm{dm}^{-3}$ & $\mathrm{mg} \mathrm{dm} \mathrm{m}^{-3}$ & $\begin{array}{c}\mathrm{CaCl}_{2} \\
0,01 \mathrm{~mol} \mathrm{~L}^{-1}\end{array}$ & -- & ----- & $\mathrm{mol}_{\mathrm{c}}$ & 1 & -- & $(\%)$ & & $-m$ & $\mathrm{dm}^{-3}-$ & \\
\hline 17 & 15 & 16 & 4.4 & 47 & 1 & 7 & 6 & 8 & 23 & 2.4 & 19 & 18.5 & $\begin{array}{l}0 . \\
4\end{array}$ \\
\hline
\end{tabular}

and in general concluded that the seasons of fall and winter provide an approximately 6.9 higher IVDMD of marandu grass than the spring and summer. However, in the current study, although the marandu grass was fibrous, its digestibility remained above $70 \%$, probably as a result of the high CP content, of the order of $12 \%$. Moore and Mott (1973) stated that the digestibility of tropical forages lies between 55 and $60 \%$, but may decrease if the concentration of crude protein in the forage is between 4 and 6\% (Moore and Mott, 1973), or increase, with higher CP contents.

\section{Dry mass productivity of marandu grass}

In the first year, with the CBP intercrop, and in the second year for both intercrops, the forage had a greater DM yield after the corn was harvested for silage at the wet grain stage (WG) (Table 3), demonstrating that the forage's DM yield can be superior after the anticipated harvest of the annual crop, remaining in the area for a longer period, producing more and allowing a longer grazing time to animals. McWilliam (1978) asserted that the ideal temperature for the growth of tropical grasses is between 30 and $35^{\circ} \mathrm{C}$, whereas 
at 10 to $15^{\circ} \mathrm{C}$ growth is practically zero, which results in seasonal forage production. Cardoso (2001) reported that nocturnal temperatures below $15{ }^{\circ} \mathrm{C}$ do not allow for satisfactory metabolic activity and formation of tissues in the aerial part of tropical forages. Additionally, low temperatures and reduced light hours determine physiological changes in the forage, triggering the reproductive process, which will consequently reduce growth. However, although the present study was conducted in the off-season, no such temperatures were observed (Fig 1 and 2).

According to Vilela (2012), the dry matter yield of marandu grass ranges from 10 to $17 \mathrm{tha}^{-1}$ year $^{-1}$. In the present study, we obtained values ranging from 7 to approximately $16 \mathrm{t} \mathrm{ha}^{-1}$ over a period of only four months. The high dry matter yield in this period is mainly due to the efficiency of marandu grass in benefiting from the residual fertilizer applied in the annual intercrops coupled with its adaptability to acid tropical soils, which predominate in the Cerrado regions, and its tolerance to the leafhopper (Argel et al., 2005).

\section{Materials and Methods}

\section{Management of forages}

Weeds in the experimental area were dried to form mulch for the NT system, using the herbicide Glyphosate $\left(1.44 \mathrm{~kg} \mathrm{ha}^{-1}\right.$ active ingredient). Plants were then harvested using a horizontal plant residue chopper (Tritton). Each experimental unit (plot) consisted of seven corn rows spaced $0.45 \mathrm{~m}$ apart, with an area of $3.6 \times 21 \mathrm{~m}\left(75.6 \mathrm{~m}^{2}\right)$. In the CB intercrop, the corn was planted together with marandu grass mechanically, using a seeder-fertilizer with a shaft-type furrowing mechanism (machete) for the NT system, at a depth of approximately $0.03 \mathrm{~m}$.

The corn sowing density was around 3.0 seeds per meter, aiming at a population of around 66,000 plants per hectare, using Simple Hybrid DKB 390 YG, recommended for the region. In the CBP intercrop, the dwarf pigeon pea was sown immediately after the corn, in the inter-rows, spaced $0.45 \mathrm{~m}$ apart, using six to eight seeds per meter. Therefore, the space between corn and dwarf pigeon pea rows was $0.45 \mathrm{~m}$, in alternate rows. As starter fertilization, in both crop years, 350 $\mathrm{kg} \mathrm{ha}^{-1}$ of the 09-28-16 formulation were applied in the corn rows.

The marandu grass seeds were stored in the fertilizer compartment of the seeder and deposited at a depth of 0.06 $\mathrm{m}$, with $0.45 \mathrm{~m}$ spacing, using approximately $7 \mathrm{~kg} \mathrm{ha}^{-1}$ of pure, viable seeds (CV 72\%). Thus, the grass seeds were located underneath the corn and/or pigeon pea seeds, following recommendations of Kluthcouski et al. (2000), aiming to slow the emergence of the forage grass in relation to the grain-producing crop to reduce the likely competition of the species in the initial period of development of the corn. The intercropped species were sown on 12/12/2013 and $12 / 06 / 2014$, for the 1 st and 2 nd crop years, respectively. Topdressing fertilization was applied on $01 / 08 / 2014$ for the first year and on 01/09/2015 for the second year, both with the $\mathrm{N}$ dose of $100 \mathrm{~kg} \mathrm{ha}^{-1}$, using urea as the source.

To evaluate the wet grain yield, the corn was harvested at $28 \%$ moisture, on $03 / 08 / 2014$ and $03 / 09 / 2015$, for the first and second crop years (after the appearance of the black layer), respectively. The dry grains had a moisture content lower than 20\% on 07/04/2014 (first year) and 08/04/2015 (second year), which were the dates when grain yield was determined in the plots (corrected for 13\% moisture). For the analysis of grain yield, the three 5-m center rows were evaluated.

Thirty days after the corn was harvested for both wet and dry grains. The plot-leveling cut was made using a motorized mower at an average height of $0.25 \mathrm{~m}$ above the soil. This management aimed to stimulate basal tillering of the forage. Thus, after this operation, the material remained still on the ground. Thirty days after the plot-leveling cut, and also 30 days after each cut $(05 / 07 / 2014,06 / 07 / 2014,07 / 07 / 2014$, and $08 / 07 / 2014$ for WG and 06/07/2014, 07/07/2014, and 08/07/2014 for DG; 05/08/2015, 06/08/2015, 07/08/2015, and $08 / 08 / 2015$ for WG and 06/08/2015, 07/08/2015, and 08/08/2015 for DG), $1 \mathrm{~m}^{2}$ of the plots (average of three samples per plot) was collected for determination of fresh matter and subsequent dry matter (oven-drying at $65^{\circ} \mathrm{C}$ until reaching a constant mass) for grinding and subsequent analyses.

\section{Location and soil-climatic conditions}

The experiment was conducted during the crop years of $2013 / 14$ and 2014/15, in an experimental area belonging to the Faculty of Engineering at UNESP, on Ilha Solteira campus, located in Selvíria - MS, Brazil. The approximate geographical coordinates are $51^{\circ} 22^{\prime} \mathrm{W}$ and $20^{\circ} 22^{\prime} \mathrm{S}$ and 335 $\mathrm{m}$ altitude. The soil in the area is an Oxisoil with clayey texture. The average annual precipitation is $1,370 \mathrm{~mm}$; air temperature and humidity (annual averages) are $23.5{ }^{\circ} \mathrm{C}$ and 70 to $80 \%$, respectively. Monthly values for precipitation $(\mathrm{mm})$, air relative humidity $(\%)$, and maximum, mean, and minimum temperatures $\left({ }^{\circ} \mathrm{C}\right)$ in the cultivation area during the experiment, in both crop years (2013/2014 and 2014/2015), are described in Figures 1 and 2.

\section{Experimental conditions}

The experiment was set up as a randomized block design with six replications, in a $2 \times 2 \times 2$ factorial arrangement consisting of two simultaneous intercrops at sowing (CB corn intercropped with Urochloa brizantha cv. Marandu (marandu grass) and CBP - corn intercropped with marandu grass and dwarf pigeon pea (Cajanus cajan cv. Anão)); two corn grain-stage harvest times (wet and dry grain); and two crop years (2013/14 and 2014/15). Aiming to characterize the soil before the intercrops were sown, its fertility was analyzed (Raij et al., 2001) in the $0-0.10 \mathrm{~m}$ and $0.10-0.20 \mathrm{~m}$ layers (Tables 5 and 6 , respectively).

Based on the soil analysis results, dolomitic limestone $(\mathrm{PRNT}=85 \%)$ was applied in the soil at the dose of $2.0 \mathrm{t} \mathrm{ha}^{-}$ 1 , on $10 / 09 / 2013$, as topdressing and without incorporation, given the history of 10 years in the no-tillage (NT) system.

\section{Biochemical Analyses}

After being ground, plant samples (dry matter) were sent to the laboratory for determination of the crude protein (CP), neutral detergent fiber (NDF), acid detergent fiber (ADF), cellulose (ADF minus LIG), hemicellulose (NDF minus $\mathrm{ADF}$ ), lignin, and ash contents. These determinations followed methodologies described by Silva and Queiroz (2002) and Campos et al. (2004), in addition to total digestible nutrients (TDN) (Cappelle et al., 2001) (Equation $1)$.

$T D N=83.79-0.4171 \times N D F$ 


\section{Statistical analyses}

All results were subjected to analysis of variance (ANOVA) and, according to the significance level of the F test, means were compared by Tukey's test at 5\% significance level.

\section{Conclusion}

Irrespective of the intercrop, the harvest of wet corn grains for silage minimized losses due to climatic factors as compared with the harvest of dry grains, in addition to providing greater dry matter yield to the marandu grass in succession. The intercrop of corn with marandu grass and dwarf pigeon pear reduced the corn grain yield and the dry matter yield of the marandu grass in succession. The marandu grass in succession to the intercrop of corn with dwarf pigeon pea resulted in better nutritional value because of the lower neutral (NDF) and acid (ADF) detergent fiber and higher total digestible nutrient (TDN) contents.

\section{Acknowledgments}

The authors thank FAPESP for the fellowship grant (Case no. 2013/17862-5) and for the research support (Case no. 2014/09165-5.)

\section{References}

Argel PJ, Miles JW, Guiot JD, Cuadrado H, Lascano CE (2005) Cultivar Mulato II (Brachiaria híbrida CIAT 36087): high quality grass and forage production, resistant to leafhoppers and adapted to tropical acid soils. Cali: CIAT.p 28.

Campos FP, Nussio CMB, Nussio LG (2004) Food analysis methods. $1^{\text {st }}$. Piracicaba: Fealq. 135 p.

Cappelle ER, Valadares Filho SC, Silva JFC, Cecon PR (2001) Estimates of energy value from chemical and qualitative characteristics of the food. Rev Bras Zootec. 30 (6): 1837-1856.

Cardoso GC (2001) Some practical factors of pastures irrigation. Paper presented at the second symposium national on beef cattle production. Federal University of Viçosa, Viçosa, 14-17 June 2001.

Brasil. (2010) Department of Agricultural Policy, agricultural and livestock plant. $1^{\text {st }}$. Brasília: Embrapa. 48 p.

Balbinot JRAA, Moraes A, Veiga M, Pelissari A, Dieckow J (2009) Crop-livestock system: intensified use of agricultural lands. Cienc Rural. 39 (6):925-1933.

Benett CGS, Buzetti S, Silva KS, Bergamaschine AF, Fabricio JA (2008) Productivity and quality composition of Marandu grass to sources and doses of nitrogen. Cienc Agrotec. 32 (5):1629-1636.

Borghi E, Crusciol CAC (2007) Corn yield, spacing and intercropping modalities with Brachiaria brizantha in notillage system. Pesqui Agropec Bras. 42 (2):163-171.

Borghi E, Mobricci C, Pulz AL, Ono EO, Crusciol, CAC (2007) Growth of Brachiaria brizantha with corn intercropping in no-tillage. Acta Sci-Agron. 29 (1):91-98.

Carneiro MAC, Cordeiro MAS, Assis PCR, Moraes ES, Pereira HS, Paulino HB, Souza ED (2008) Phytomass yield of different cover crops and alterations in the microbial activity in a cerrado soil in brazil. Bragantia. 67 (2):455462.

Conab. (2012) Accompaniment of the Brazilian crop: twelfth survey, september of 2011. Disponible in: Access in: 24 nov. 2011.
Costa KAP, Rosa B, Oliveira IP, Custódio DP, Silva DCE (2005) Effect of seasonal climate condition on the dry matter production and bromatological composition of Brachiaria brizantha cv. Marandu. Ci Anim Bras. 6 (3):187-193.

Cobucci T, Kluthcouski J, Aidar, H (2001) Santa Fé System: forage production in the off season. In: Cobucci $\mathrm{T}$, Kluthcouski J, Aidar, H (ed) Documento, 123. Embrapa Arroz e Feijão, Santo Antonio de Goiás. p.125-135.

Ferreira EPB, Stone LF, Partelli FL, Didonet AD (2011) Grain yield of common bean as affected by cover crops and soil management systems. Rev Bras Eng Agric Ambient. 15 (7):695-701.

Gerdes L, Werner JC, Colozza MT, Possenti RA, Schammass EA (2000) Evaluation of Nutritive Characteristics of the Grasses Brachiaria brizantha cv. Marandu, Setaria sphacelata cv. Kazungula and Panicum maximum cv. Tanzânia in the Seasons of the Year. Rev Bras Zootecn. 29 (4):955-963.

Heinrichs R, Vitti GC, Moreira A, Figueiredo PAM, Fancelli AL, Corazza EJ (2005) Soil chemical characteristics and green manure yield in a corn intercropped system. Rev Bras Cienc Solo. 29 (1):71-79.

Kluthcouski J, Cobucci T, Aidar H, Yokoyama LP, Oliveira IP, Costa JLS, Vilela L, Barcellos AO, Magnabosco CU (2000) Santa Fe System - Embrapa Technology: Integration Crop-Livestock by the consortium of annual crops with forages in crop areas in direct and conventional systems. $1^{\text {st }}$. Santo Antônio de Goiás: Embrapa Arroz e Feijão. 28 p.

Leite GG, Euclides VPB (1994) Use of Brachiaria pastures. Paper presented at the $11^{\text {th }}$ symposium on pasture management, Fealq, Piracicaba, 8-12 October 1994.

Lemaire G, Franzluebbers A, Carvalho PCF, Dedieu B (2014) Integrated crop-livestock systems: Strategies to achieve synergy between agricultural production and environmental quality. Agr Ecosys Environ. 190: 4-8.

Leonel FP, Pereira JC, Costa MG, Marco Júnior P, Lara LA, Queiroz AC (2009) Productive performance and nutritional characteristics of signal grass intercropped with corn. Rev Bras Zootecn. 38 (1):177-189.

Mc William JR (1978) Response of pasture plants to temperature. In: Wilson JR (ed). Plant relation in pasture. CSIRO, Melbourne. p 17-34.

Maranhão CMA, Silva CCF, Bonomo P, Pires AJV (2009) Production and chemical-bromatological composition of two cultivars of Brachiaria fertilized with nitrogen and its relationship with the SPAD. Acta Sci-Agron. 31 (2):117122.

Moore JE, Mott GO (1973) Structural inhibitors of quality in tropical grasses. In: Matches AG Anti quality components of forages. Madison: CSSA, Special publication, 4:53-98.

Muraishi CT, Leal AJF, Lazarini E, Rodrigues LR, Gomes Júnior FG (2005) Soybean and corn yield in no tillage system with different intervals among different covering handlings. Acta Sci-Agron. 27 (2):193-198.

Nunes HV, Silva IF, Bruno RLA, Barros DI, Pereira WE (2006) Culture systems, velvet bean and mineral fertilization influence on maize seeds physiological quality. Rev Bras Sementes. 28 (3):6-12.

Oliveira AM, Silva PSL, Albuquerque CC, Azevedo CMSB, Cardoso MJ, Oliveira OF (2011) Weed control in corn via intercropping with gliricidia sown by broadcasting. Planta Daninha. 29 (3):535-543.

Partelli FL, Vieira HD, Ferreira, EPB, Viana AP, Espindola JAA, Boddey SURM (2011) Biologic dinitrogen fixation and nutrient cycling in cover crops and their effect on 
organic Conilon coffee. Semina: Cien Agrarias. 32 (3):9951006.

Pedreira MS, Berchielli TT (2006) Minerals. In: Berchielli, TT, Pires AV, Oliveira SG (ed). Ruminant nutrition. $1^{\text {st }}$. Funep, Jaboticabal. p 333-350.

Raij BV, Andrade JC, Cantarella H and Quaggio JA (2001) Chemical analysis to evaluate the fertility of tropical soils. $1^{\text {st }}$. Campinas: Instituto Agronômico. $284 \mathrm{p}$.

Ryschawy J, Choisis N, Joannon A, Gibon A (2012) Mixed crop-livestock systems: An economic and environmentalfriendly way of farming? Animal. 6 (10):1722-1730.

Sanderson MA, Archer D, Herndrickson J, Kronberg S, Liebig M, Nichols C, Schmer M, Tanaka D, Aguilar J (2013) Diversification and ecosystem services for conservation agriculture: Outcomes from pastures and integrated crop-livestock systems. Renew. Agr Food Syst. 28 (2):129-144

Santos PA, Silva AF, Carvalho MAC, Caione G (2010) Green manures and covering nitrogen fertilization in maize. Rev Bras Milho Sorgo. 9 (2):123-134.

Salton JC, Mercante FM, Tomazi M, Zanatta JA, Concenço G, Silva WM, Retore M (2014) Integrated crop-livestock system in tropical Brazil: Toward a sustainable production system. Agr Ecosyst Environ. 190: 70-79.

Senaratine R, Liyanage NDL, Soper RJ (1995) Nitrogen fixation and $\mathrm{N}$ transfer from Cowpea, mungbean and groundnut when intercropped with maize. Fert Res. 40: 4148 .
Silva DJ, Queiroz AC (2002) Food analysis: chemical and biological methods. $3^{\text {rd }}$. Viçosa: Federal University of Viçosa. $165 \mathrm{p}$.

Silva DA, Vitorino ACT, Souza LCF, Gonçalves MC, Roscoe R (2006) Previous crop and nitrogen fertilization in corn under no-tillage system. Rev Bras Milho Sorgo. 5 (2):75-88.

Silveira PM, Braz AJBP, Kliemann HJ, Zimmermann FJP (2005) Nitrogen fertilization of common bean grown under no-tillage system after several cover crops. Pesqui Agropecu Bras. 40:377-381.

Soest PJ van (1994) Nutritional ecology of the ruminant. $2^{\text {nd }}$. New York: Cornell University. $476 \mathrm{p}$.

Vilela H (2012) Selection of forage plants, fertilization implantation. $2^{\text {nd }}$. Viçosa - MG: Aprenda Fácil. 111 p.

Weber MA, Mielniczuk J (2009) Soil nitrogen stock and availability in a long-term experiment. Rev Bras Cienc Solo. 33 (2):429-437.

Wilson JR (1983) Effects of water stress on in vitro dry matter digestibility and chemical composition of herbage of tropical pasture species. Aust J Agric Res. 34:377-390.

Wilkins PW, Allen DK, Mytton LR (2000) Differences in the nitrogen use efficiency of perennial ryegrass varieties under simulated rotational grazing and effects on nitrogen recovery and herbage nitrogen content. Grass Forage Sci. 55:69-76.

Wright IA, Tarawal S, Blümmel M, Gerard B, Teufel N, Herrero M (2012) Integrating crops and livestock in subtropical agricultural systems. J Sci Food Agric. 92 (5):1010-1015. 